KONRAD MARCINIUK ${ }^{1}$

\title{
Kilka uwag do założeń do projektu ustawy o zmianie ustawy o zagospodarowaniu wspólnot gruntowych ${ }^{2}$
}

Wspólnoty gruntowe stanowią szczególną kategorię nieruchomości. Jej wyodrębnienie dokonało się w rezultacie historycznych przemian w strukturach społeczno-ekonomicznych, do jakich doszło na ziemiach polskich przede wszystkim w XIX i na początku XX wieku. Instytucja wspólnoty gruntowej wywodzi się bezpośrednio z dawnych form władania gruntami przez mieszkańców wsi - najpierw znajdujących swe oparcie $w$ relacjach wypływających ze stosunku poddańczego, potem zaś mających podstawę w zbiorowych tytułach prawnych, które pojawiły się w trakcie uwłaszczania włościan. Dokładniejsza analiza genezy wspólnot gruntowych wskazuje jednak, że niektóre z nich są wynikiem kształtowania się stosunków własnościowych jeszcze w epoce średniowiecza. ${ }^{3}$ Istniejąca po dziś dzień wspólnota leśna „Piwniczna-Szyja” o powierzchni ok. 1650 ha użytkowana przez mieszkańców miasta Piwniczna-Szyja na podstawie przywileju nadanego w 1348 r. przez Kazimierza Wielkiego, potwierdzanego następnie przez Zygmunta Starego, Stefana Batorego, Michała Korybuta Wiśniowieckiego, Jana Sobieskiego, Augusta II Sasa, Augusta III i Stanisława Augusta Poniatowskiego jest wręcz pomnikowym i dość wyjątkowym przykładem trwałości niektórych instytucji prawnych w kraju o tak burzliwej historii jak Polska.

Próby unifikacji pochodzących z różnych okresów i wywodzących się głównie z systemów prawnych państw zaborczych rozwiązań prawnych odnoszących się do wspólnot gruntowych były podejmowane przez ustawodawcę już w okresie międzywojennym. Przykładem mogą być wydane w 1920, 1922 i 1927 r. przepisy o zniesieniu niektórych służebności i serwitutów przysługujących rolnikom z mocy

$1 \quad$ Uniwersytet Warszawski.

2 Ministerstwo Rolnictwa i Rozwoju Wsi, Założenia do projektu ustawy o zmianie ustawy o zagospodarowaniu wspólnot gruntowych, Warszawa 2010, www.bip.minrol.gov.pl. Projekt został przyjęty przez Radę Ministrów w dniu 6 listopada 2012 r.

3 Ciekawe przykłady takich wspólnot podaje A. Stelmachowski, Relikty dawnej własności wiejskiej, (w:) Rozprawy i studia. Księga pamiątkowa dedykowana Profesorowi Aleksandrowi Lichorowiczowi, pod red. E. Kremer, Z. Truszkiewicza, Kraków 2009, s. 242-245. 
nadań cesarskich, ${ }^{4}$ a przede wszystkim ustawa z 4 maja 1938 r. o uporządkowaniu wspólnot gruntowych, ${ }^{5}$ której rozwiązania nie zostały jednak wprowadzone w życie w związku z powodu wybuchu wojny. ${ }^{6}$

W świetle unormowań współczesnych wspólnoty gruntowe stanowią nieruchomości rolne, leśne oraz obszary wodne podlegające szczególnym formom zagospodarowania w trybie i na zasadach określonych w ustawie z dnia 29 czerwca $1963 \mathrm{r}$. o zagospodarowaniu wspólnot gruntowych. ${ }^{7}$ Zgodnie z brzmieniem art. 1 wskazanej ustawy wspólnoty gruntowe obejmują:

1) grunty nadane w wyniku uwłaszczenia włościan i mieszczan-rolników na wspólną własność, we wspólne posiadanie lub do wspólnego użytkowania ogółowi, pewnej grupie lub niektórym mieszkańcom jednej albo kilku wsi,

2) grunty wydzielone tytułem wynagrodzenia za zniesione służebności, wynikające z urządzenia ziemskiego włościan i mieszczan-rolników, na wspólną własność, we wspólne posiadanie lub do wspólnego użytkowania gminie, miejscowości albo ogółowi uprawnionych do wykonywania służebności,

3) grunty powstałe $w$ wyniku podziału pomiędzy zespoły mieszkańców poszczególnych wsi gruntów, które nadane zostały przy uwłaszczeniu włościan i mieszczan-rolników mieszkańcom kilku wsi na wspólną własność, we wspólne posiadanie lub do wspólnego użytkowania,

4) grunty użytkowane wspólnie przez mieszkańców dawnych okolic i zaścianków oraz należące do wspólnot urbarialnych i spółek szałaśniczych,

5) grunty otrzymane przez grupę mieszkańców jednej lub kilku wsi na wspólną własność i do wspólnego użytkowania w drodze przywilejów i darowizn bądź nabyte w takim celu,

6) grunty zapisane w księgach wieczystych (gruntowych) jako własność gminy (gromady), jeżeli w księgach tych istnieje wpis o uprawnieniu określonych grup mieszkańców gminy (gromady) do wieczystego użytkowania i pobierania pożytków z tych nieruchomości,

7) grunty stanowiące dobro gromadzkie (gminne) będące we wspólnym użytkowaniu na terenach dawnych województw: rzeszowskiego, krakowskiego oraz powiatu cieszyńskiego województwa katowickiego. ustawa z 7 kwietnia 1922 r. zmieniająca ustawę z 7 maja 1920 r. (Dz.U. Nr. 30, poz. 304), rozporządzenie Prezydenta RP z 1 lutego 1927 r. o zniesieniu służebności w województwach: kieleckim, lubelskim, łódzkim, warszawskim i zachodniej części województwa białostockiego (Dz.U. Nr 10, poz. 74).

5 Dz.U. Nr 33, poz. 290.

$6 \quad$ Ustawa ta regulowała zasady podziału gruntów wspólnych, a w odniesieniu do gruntów niepodzielnych określała zasady ustalania na rzecz uprawnionych prawa współwłasności, a także zasady zagospodarowania i rozporządzania niepodzielonymi gruntami wspólnymi. 
Na tle takiego ujęcia definicji wspólnot gruntowych rodzi się pytanie o ich charakter prawny. Niewątpliwie zbyt daleko idącym uproszczeniem byłoby przyjęcie, że wspólnoty gruntowe stanowią rodzaj współwłasności, gdyż zgodnie z definicją ustawową pojęcie wspólnoty gruntowej obejmuje nie tylko rzeczy. Jak słusznie wskazuje M. Ptaszyk, ${ }^{8}$ w skład wspólnot gruntowych oprócz rzeczy - a więc nieruchomości rolnych, leśnych i obszarów wodnych - wchodzi także prawo użytkowania wspólnych gruntów oraz ich posiadanie. Wynika to wyraźnie z brzmienia art. 1 ust. 1 ustawy, zgodnie z którym wspólnotami gruntowymi są nieruchomości nadane [...], otrzymane [...] wydzielone [...] na wspólną własność, do wspólnego użytkowania lub posiadania. W konsekwencji należy uznać, że wspólnoty gruntowe mogą obejmować zarówno prawo własności, jak również prawa użytkowania nieruchomości.

Cechą charakterystyczną wymienionych kategorii gruntów stanowiących wspólnoty gruntowe jest więc nie tyle ich stan prawny, który może być dość zróżnicowany, ile raczej fakt ich przeznaczenia do współposiadania i wspólnego czerpania pożytków z produkcji rolnej lub leśnej prowadzonej na tych gruntach przez określoną grupę osób. Aby ocenić komu przysługuje własność gruntów stanowiących wspólnotę gruntową, każdorazowo należy sięgać do źródeł powstania wspólnoty, ale także uwzględniać zmiany, które nastąpiły przed wejściem w życie ustawy o zagospodarowaniu wspólnot gruntowych, w szczególności wynikające z nacjonalizacji, zasiedzenia, scalania gruntów. ${ }^{9} \mathrm{Na}$ tym tle należy podkreślić, że przepisy współczesnej ustawy nie dążą do uregulowania stanu prawnego wspólnot gruntowych, koncentrując się raczej na kwestiach związanych z ich zagospodarowaniem. ${ }^{10}$ Obok takich zagadnień, jak ustalanie kręgu osób uprawnionych do korzystania ze wspólnot gruntowych, ${ }^{11}$ jak również sposób ustalania przysługujących tym osobom udziałów, ${ }^{12}$ przedmiotem unormowań ustawy są przede wszystkim zagadnienia związane

M. Ptaszyk, Istota i charakter prawny wspólnoty gruntowej, „Krakowskie Studia Prawnicze” 1986, t. 19, s. 156. Stanowisko Rady Ministrów wobec poselskiego projektu ustawy o zmianie ustawy o zagospodarowaniu wspólnot gruntowych (druk nr 1469), www.sejmometr.pl.

10 Na marginesie warto wskazać, że w trybie i na zasadach określonych w omawianej ustawie, oprócz gruntów stanowiących wspólnoty gruntowe, zagospodarowaniu podlegają także nieruchomości rolne, leśne i obszary wodne, stanowiące mienie gromadzkie położone poza terenami miast i osiedli, o ile nieruchomości takie przed dniem wejścia w życie ustawy o zagospodarowaniu wspólnot gruntowych były faktycznie użytkowane wspólnie przez mieszkańców wsi (art. 1 ust. 2 i 3). Na niemożność jednolitego zakwalifikowania statusu prawnego wchodzących w skład wspólnot gruntowych gruntów gromadzkich zwrócił uwagę R. Szarek, Komunalizacja mienia gromadzkiego, „Radca Prawny” 1997, nr 6, s. 60. Zdaniem autora mienia gromadzkie stanowiące wspólnotę może być przedmiotem własności gromady (gminy) jako podmiotu prawa cywilnego bądź poszczególnych jej mieszkańców i ich grup, a nawet ogółu mieszkańców uprawnionych do korzystania z danych nieruchomości. Patrz także R. Szarek, Wspólnoty gruntowe - czy mają jeszcze rację bytu, „Finanse Komunalne” 2008, nr 10.

Uprawnionymi do udziału we wspólnocie gruntowej są osoby fizyczne lub prawne posiadające gospodarstwa rolne, jeżeli w ciągu ostatniego roku przed dniem wejścia w życie ustawy (tj. przed 5 lipca 1963 r.) faktycznie korzystały z tej wspólnoty (art. 6 ust. 1).

Udziały poszczególnych uprawnionych we wspólnocie gruntowej określa się w idealnych (ułamkowych) częściach. Wielkość tych udziałów ustala się w ten sposób, że połowę wspólnoty dzieli się pomiędzy uprawnionych w równych częściach, drugą zaś połowę - proporcjonalnie do obszarów gruntów posiadanych przez każdego z uprawnionych, a położonych na obszarze tej samej lub graniczącej z nią gminy (art. 9 ust. 1 i 2). 
z tworzeniem i funkcjonowaniem spółek do zagospodarowania wspólnot gruntowych, jako obligatoryjnych ${ }^{13}$ i posiadających szczególną konstrukcję prawną form organizacyjnych wykonywania uprawnień wobec wspólnoty gruntowej. ${ }^{14}$

Podsumowując powyższe - z konieczności skrótowe uwagi wstępne dotyczące charakteru prawnego wspólnot gruntowych - warto odwołać się do definicji sformułowanej przez M. Ptaszyka, który zdefiniował wspólnoty gruntowe jako zespół praw rzeczowych (własności lub użytkowania) na nieruchomościach gruntowych:

1) pochodzących z określonych ustawowo źródeł (art. 1 ust. 1 ustawy o zagospodarowaniu wspólnot gruntowych),

2) pozostających we wspólnym użytkowaniu określonej umownie lub administracyjnie grupy mieszkańców wsi, posiadających miejsce zamieszkania lub gospodarstwo rolne w danej miejscowości,

3) użytkowanych obowiązkowo w ramach specjalnie w tym celu powołanej osoby prawnej..$^{15}$

Istotnym problemem związanym z funkcjonowaniem wspólnot gruntowych we współczesnym obrocie gospodarczym jest ich ustawowe wyłączenie spod regulacji wieczystoksięgowej. Przepis art. 11 ustawy o zagospodarowaniu wspólnot wprost przewiduje, że dla nieruchomości stanowiących wspólnotę gruntową nie prowadzi się ksiąg wieczystych, a dotychczasowe księgi wieczyste tracą moc i podlegają zamknięciu. W piśmiennictwie słusznie wskazuje się, że rozwiązanie takie udaremnia w zakresie nieruchomości, do których się odnosi, realizację takich dóbr jak jawność uprawnień, rękojmia wiary publicznej ksiąg wieczystych czy też możliwość obciążania nieruchomości hipoteką. ${ }^{16}$

Według najnowszych danych na terytorium Rzeczypospolitej Polskiej istnieje ponad 5100 wspólnot gruntowych o łącznej powierzchni ok. 107000 ha. Powołane przez udziałowców spółki zarządzają 1080 wspólnotami, z tym że właściwe organy powołano tylko w 1073 spółkach. Statuty przyjęły 1064 spółki, przy czym statuty zostały zatwierdzone przez wójtów, burmistrzów lub prezydentów miast w 1014 przypadkach. Nadto właściwe organy utworzono w 54 przypadkach spółek przymusowych. Wykazem uprawnionych do udziału we wspólnotach dysponowało 1527

Osoby uprawnione do udziału we wspólnocie gruntowej powinny utworzyć spółkę do sprawowania zarządu nad wspólnotą i do właściwego zagospodarowania gruntów wchodzących w skład tej wspólnoty (art. 14 ust. 1 ustawy). W przypadkach wskazanych w art. 25 ust. 1 ustawy wójt (burmistrz, prezydent miasta) uprawniony jest do utworzenia spółki przymusowej oraz do nadania jej statutu, a także do wyznaczenia organów spółki spośród osób uprawnionych do udziału we wspólnocie gruntowej.

Problematykę konstrukcji spółek do zagospodarowania wspólnot gruntowych opisuje szerzej M. Ptaszyk, Spółki do zagospodarowania wspólnot gruntowych - sytuacja prawna, funkcjonowanie, perspektywy, Kraków 1989. Zob. także J. Szachułowicz, Spółki prawa administracyjnego, „Przegląd Sądowy” 2004, nr 2, s. 10-12. 
wójtów (burmistrzów, prezydentów miast). Jednocześnie wskazuje się, że w przypadku prawie 3500 wspólnot gruntowych nie zostały wydane decyzje ustalające, które nieruchomości stanowią wspólnotę gruntową oraz ustalające wykaz uprawnionych do udziału w tej wspólnocie. ${ }^{17}$ Powyższe dane wskazują, że ok. $75 \%$ wspólnot gruntowych nie ma uporządkowanego, zgodnie z przepisami ustawy, stanu prawnego, co oznacza także, że wspólnoty te nie zostały zagospodarowane w sposób nakazany przez ustawodawcę. Jak wskazują autorzy założeń do projektu ustawy zmieniającej ustawę o zagospodarowaniu wspólnot gruntowych, taka sytuacja stwarza poważne niedogodności dla samorządów gminnych przy opodatkowaniu tych gruntów oraz pozyskiwaniu ich na cele związane z realizacją miejscowych planów zagospodarowania przestrzennego. Utrzymywanie w niezmienionym kształcie rozwiązań legislacyjnych, które w ciągu 49 lat obowiązywania nie doprowadziły do realizacji swoich podstawowych założeń, wydaje się zatem nieracjonalne. Dodatkową przesłanką zmiany uregulowań prawnych odnoszących się do wspólnot gruntowych są także głębokie przeobrażenia ustrojowe i gospodarcze, które miały miejsce w Polsce na przestrzeni ostatnich dwudziestu lat.

Podnoszona w piśmiennictwie konieczność dostosowania przepisów ustawy do współczesnych realiów społeczno-gospodarczych i funkcjonującego prawodawstwa została dostrzeżona także przez Ministra Rolnictwa. Wyrazem podjętych działań jest projekt założeń do ustawy o zmianie ustawy o zagospodarowaniu wspólnot gruntowych. ${ }^{18}$ Planowane zmiany zmierzają przede wszystkim do uregulowania stanów prawnych gruntów stanowiących wspólnoty gruntowe, niebędących jednocześnie mieniem gromadzkim. O ile opracowany w myśl przyjętych założeń projekt ustawy zostanie uchwalony, wydaje się, że stworzy on dość efektywne instrumenty pozwalające na osiągnięcie tak postawionego celu. Pojawia się jednak pytanie, czy przyjęty kierunek regulacji stanów prawnych wspólnot gruntowych jest właściwy, tj. czy wspólnoty gruntowe, których stan prawny zostanie uregulowany w myśl przyjętych założeń, przyczyni się do ich bardziej efektywnego wykorzystania gospodarczego, względnie ułatwi dokonywanie racjonalnych rozporządzeń.

Przyjęte przez Radę Ministrów założenia projektu zakładają, że wspólnoty gruntowe, które dotychczas funkcjonują zgodnie z przepisami ustawy, a więc w których znane są wielkości udziałów wszystkich uprawnionych do wspólnoty, a zarządzanie nią odbywa się w ramach spółki utworzonej przez uprawnionych, będą mogły funkcjonować nadal w dotychczasowej formie organizacyjnej i gospodarować na dotychczasowych zasadach, jeżeli taka będzie wola samych uprawnionych. Przyjęcie takiego rozwiązania bez wątpienia zasługuje na aprobatę. W wielu przypadkach wspólnoty gruntowe są osadzone głęboko w lokalnej tradycji i zwycza-

Takie dane podaje Ministerstwo Rolnictwa i Rozwoju Wsi w opublikowanych w 2010 roku założeniach do projektu ustawy o zmianie ustawy o zagospodarowaniu wspólnot gruntowych (www.bip.minrol.gov.pl). 
jach oraz pełnią na tyle istotną funkcję w społeczności lokalnej, że ich istnienia nie należy rozpatrywać tylko i wyłącznie w kategoriach gospodarczych. Pozostawienie prawnej możliwości utrzymania dotychczasowych rozwiązań pozwala mieć nadzieję, że utrzymana zostanie w szczególności wspomniana na wstępie istniejąca od przeszło 660 lat wspólnota leśna „Piwniczna-Szyja”.

Kolejna propozycja zmian dotyczy z kolei możliwości przekształcenia wspólnot gruntowych - bez względu na to, czy w chwili obecnej stanowią one rodzaj wspólwłasności uprawnionych, czy też obejmują jedynie prawo użytkowania nieruchomości stanowiących w istocie cudzą własność - we współwłasność w rozumieniu art. 195 kodeksu cywilnego. W myśl przyjętych założeń przekształcanie wspólnoty we współwłasność miałoby następować w drodze uchwały podejmowanej jednogłośnie, a jeżeli uzyskanie jednomyślności głosujących okazałoby się niemożliwe, osoby, którym przysługuje ponad połowa udziałów we wspólnocie, mogłyby żądać rozstrzygnięcia przez sąd, który orzekałby, mając na względzie cel zamierzonej czynności oraz interesy wszystkich uprawnionych do wspólnoty. Przekształcenie takie mogłoby dotyczyć tylko tych wspólnot gruntowych, w których znane są wielkości udziałów wszystkich uprawnionych oraz dla których utworzono spółki do sprawowania zarządu. Uchwała o przekształceniu wymagałaby zachowania formy aktu notarialnego i stanowiłaby podstawę do ujawnienia współwłasności zarówno w ewidencji gruntów i budynków, jak i w księdze wieczystej. Wielkość udziałów przysługujących poszczególnym współwłaścicielom byłaby pochodną udziałów, jakie przysługiwały im we wspólnocie gruntowej. Uchwała o przekształceniu wspólnoty we współwłasność (względnie orzeczenie sądu wydane na podstawie art. 199 kodeksu cywilnego) stanowiłaby także podstawę do rozwiązania i likwidacji spółki do zagospodarowania tej wspólnoty gruntowej. W myśl przyjętych założeń wskazane przekształcenie, obok aspektu prawnomaterialnego uregulowania własności gruntów stanowiących dotychczas wspólnotę gruntową, prowadziłoby także do urządzenia dla tych nieruchomości ksiąg wieczystych oraz ujawnienia w działach II tych ksiąg współwłaścicieli.

Próba oceny zaproponowanej zmiany nie prowadzi do jednoznacznego wniosku. Z jednej strony niewątpliwie na aprobatę zasługuje stworzenie możliwości przekształcenia wspólnoty we współwłasność, co teoretycznie tworzyłoby całkowicie czytelny stan prawny tych gruntów, a poprzez urządzenie ksiąg wieczystych i ujawnienie w nich dotychczasowych współuprawnionych zapewniałoby im możliwość korzystania np. z ochrony, jaką zapewnia rękojmia wiary publicznej ksiąg wieczystych. Dodatkowo współwłaściciele uzyskaliby np. możliwość ustanawiania hipotek, a w konsekwencji dostęp m.in. do kredytów hipotecznych. Bez wątpienia w pewnych warunkach rozwiązanie takie może okazać się dla dotychczasowych współuprawnionych do wspólnoty bardzo korzystne. Z drugiej strony nie sposób nie zgłosić wątpliwości co do racjonalności tego typu przekształceń z punktu wi- 
dzenia dalszego wykorzystywania gospodarczego tego typu nieruchomości, a także dokonywania rozporządzeń, których nieruchomości takie miałyby być przedmiotem. W przypadku przekształcenia wspólnoty gruntowej we współwłasność, jej przedmiot podlegałby przepisom Działu IV, Tytułu I, Księgi II Kodeksu cywilnego. Należy zastanowić się, na ile przepisy te stanowią efektywne narzędzie sprawowania zarządu nad nieruchomościami rolnymi i leśnymi. W literaturze podkreśla się, że współwłasność w częściach ułamkowych jest zasadniczo stanem tymczasowym, niekiedy przypadkowym, częstokroć niepożądanym. ${ }^{19}$ Stosunek współwłasności w praktyce stwarza wiele trudności w toku wykonywania zarządu, współposiadania i korzystania z rzeczy wspólnej, a w konsekwencji może stać się zarzewiem licznych konfliktów między współwłaścicielami. Stopień złożoności relacji pomiędzy współwłaścicielami, a wraz z nim ryzyko występowania konfliktów rośnie wraz z liczbą współwłaścicieli. Dostrzega to zresztą sam ustawodawca. Za przykład mogą posłużyć uregulowania przyjęte w art. 19 ustawy z 24 czerwca 1994 r. o własności lokali, ${ }^{20}$ zgodnie z którymi do zarządu nieruchomością wspólną stosuje się odpowiednio przepisy kodeksu cywilnego i kodeksu postępowania cywilnego o współwłasności, tylko o ile liczba lokali wyodrębnionych i lokali niewyodrębnionych, należących nadal do dotychczasowego właściciela, nie jest większa niż siedem. W przypadku gdy liczba lokali jest większa, ich właściciele zobowiązani są powierzyć zarząd wspólnoty mieszkaniowej jedno- lub wieloosobowemu zarządowi. Niewątpliwie rozwiązanie takie zostało podyktowane troską o efektywność sprawowania zarządu.

Biorąc pod uwagę fakt, że w praktyce krąg uprawnionych do wspólnoty gruntowej obejmuje nierzadko kilkadziesiąt osób, trudno sobie wyobrazić, aby po przekształceniu wspólnoty we współwłasność, przy jednoczesnym zlikwidowaniu spółki sprawującej dotychczas zarząd wspólnotą oraz poddaniu zarządu wspólnej nieruchomości reżimowi przepisów kodeksu cywilnego, efektywność działań gospodarczych wzrosła. $Z$ tego też punktu widzenia należy zakładać, że racjonalne decyzje dotyczące przekształcenia wspólnoty we współwłasność mogłyby być podejmowane tylko i wyłącznie w celu likwidacji wspólnoty poprzez zniesienie współwłasności powstałej wskutek takiego przekształcenia. Tymczasem także realizacja tego celu może okazać się niezmiernie trudna. Należy pamiętać, że z natury rzeczy wspólnoty gruntowe to w przeważającej mierze grunty rolne. Zarówno rozporządzenie udziałem, podział, jak i znoszenie współwłasności nieruchomości stanowiących grunty rolne jest przedmiotem szczególnych regulacji.

Por. E. Gniewek, Prawo rzeczowe, Warszawa 2000, s. 145; idem, Kodeks cywilny. Księga druga. Własność i inne prawa rzeczowe. Komentarz, Kraków 2001, s. 431; J. Ignatowicz, (w:) Kodeks cywilny, t. 1, Warszawa 1972, pod red. J. Ignatowicza i J. Pietrzykowskiego, s. 541; Z.K. Nowakowski, (w:) System prawa cywilnego, t. II, Wrocław 1977, s. 421-422; S. Rudnicki, (w:) Komentarz do KC, Księga druga, Własność i inne prawa rzeczowe, Warszawa 2001, s. 262. 
Wychodząc z założenia, że w zasadzie wszyscy, a przynajmniej większość współwłaścieli nieruchomości stanowiącej wcześniej wspólnotę gruntową, będzie spełniać warunek, o którym mowa w art. 166 kc. dotyczący prowadzenia na nieruchomości wspólnej gospodarstwa rolnego, można spodziewać się komplikacji związanych ze zbywaniem przez poszczególnych współwłaścicieli udziałów we współwłasności. Zgodnie z brzmieniem art. 166 kc., w razie sprzedaży przez współwłaściciela nieruchomości rolnej udziału we współwłasności lub części tego udziału, pozostałym współwłaścicielom przysługuje prawo pierwokupu, jeżeli prowadzą gospodarstwo rolne na gruncie wspólnym. W piśmiennictwie podkreśla się, że prowadzenie gospodarstwa na gruncie wspólnym obejmuje trzy sytuacje:

1) współwłaściciele wspólnie prowadzą gospodarstwo rolne na wspólnej nieruchomości,

2) gospodarstwo jest prowadzone na wspólnym gruncie przez jednego ze współwłaścicieli (np. zarządcę),

3) współwłaściciele prowadzą odrębne gospodarstwa na części gruntu wydzielonej w ramach podziału do używania (quoad usum). ${ }^{21}$

W konsekwencji w przypadku zbywania udziałów we współwłasności nieruchomości przekształconej ze wspólnoty gruntowej będzie zapewne dochodzić do częstych sytuacji zbiegu uprawnień pozostałych współwłaścicieli wynikających z prawa pierwokupu, o którym mowa w art. 166 kc. Nie będzie to dotyczyć jedynie wypadków, gdy nieruchomość utraci wcześniej rolny charakter oraz wypadków, gdy współwłaściciele prowadzący jednocześnie gospodarstwa rolne będą sprzedawać swoje udziały we współwłasności wraz z tym gospodarstwem albo gdy nabywcą udziału będzie inny współwłaściciel lub osoba, która dziedziczyłaby gospodarstwo po sprzedawcy.

Zgodnie z art. 93 ust. 2a ustawy z 21 sierpnia 1997 r. o gospodarce nieruchomościami ${ }^{22}$ podział nieruchomości położonych na obszarach przeznaczonych w planach miejscowych na cele rolne i leśne, a w przypadku braku planu miejscowego wykorzystywanych na cele rolne i leśne, powodujący wydzielenie działki gruntu o powierzchni mniejszej niż 0,3000 ha, jest dopuszczalny, tylko o ile wydzielana działka zostanie przeznaczona na powiększenie sąsiedniej nieruchomości lub dokonana zostanie regulacja granic między sąsiadującymi nieruchomościami. Dodatkowo, w przypadku gdyby grunt przekształconej we współwłasność wspólnoty gruntowej stanowil gospodarstwo rolne w rozumieniu art. $553 \mathrm{kc}$., zniesienie jego współwłasności w drodze sądowej podlegałoby ograniczeniom wynikającym z art. 213-218 kc. W każdym razie jednak należy stwierdzić, że znoszenie współwłasno- 
ści nieruchomości rolnych w drodze podziału rzeczy wspólnej, jako prowadzące do rozdrobnienia struktury obszarowej takich nieruchomości, nie wydaje się rozwiązaniem racjonalnym z punktu widzenia zasad prawidłowej gospodarki rolnej ani nie wpisuje się w ogólny nurt polityki wobec struktur rolnych, zarówno w wymiarze krajowym, jak i w płaszczyźnie prawa Unii Europejskiej. Z tego też względu należy mieć nadzieję, że w trakcie prac nad projektem ustawy o zmianie ustawy o zagospodarowaniu wspólnot gruntowych zostaną uwzględnione zagadnienia związane z wykonywaniem zarządu, współposiadaniem i korzystaniem ze wspólnej nieruchomości przez - jak należy się spodziewać - liczne grupy współwłaścicieli. Dodatkowo nie powinno zabraknąć przepisów dotyczących znoszenia współwłasności, które z jednej strony umożliwiałyby sprawne „wychodzenie” ze współwłasności, która - jak wskazano powyżej - ma co do zasady charakter przejściowy, a z drugiej uwzględniałyby specyfikę przedmiotów tej współwłasności jako nieruchomości przede wszystkim rolnych i leśnych. Należy wyrazić obawę, że bez jednoczesnego uregulowania zasad znoszenia współwłasności, względnie uregulowania zasad korzystania z rzeczy wspólnej przez współwłaścicieli (np. w postaci wprowadzenia obowiązku zawierania umowy o korzystanie z rzeczy wspólnej, której postanowienia podlegałyby ujawnieniu w dziale III księgi wieczystej), przekształcenie wspólnoty gruntowej we współwłasność może spowodować daleko większe komplikacje dla współwłaścicieli niż pozostawienie wspólnoty gruntowej w jej dotychczasowym kształcie. Być może wreszcie należałoby sięgnąć do rozwiązań przyjętych w ustawie z 1938 roku, która wprowadzała dla niepodzielonych wspólnot daleko idące ograniczenia w obrocie ich gruntami, a nawet w rozporządzaniu na wypadek śmierci - mając na względzie potrzebę zachowania ich w dobrej kondycji ekonomicznej i nierozdrabniania. ${ }^{23}$

Można wreszcie rozważyć koncepcję, która wprawdzie dość daleko odbiega od przyjętych założeń ministerialnych, aby dla wspólnot o uporządkowanym stanie prawnym, zarządzanych przez funkcjonujące spółki prawa administracyjnego stworzyć możliwość przekształcenia tych spółek w jedną z form spółek prawa handlowego, a następnie uwłaszczenia tak powstałych spółek na gruntach stanowiących wspólnotę, czemu oczywiście towarzyszyłoby urządzenie ksiąg wieczystych dla tych nieruchomości. Wydaje się, że takie rozwiązanie, pozwalające uchronić integralność gruntów wspólnotowych - także w płaszczyźnie własnościowej - mogłoby stanowić ciekawą alternatywę dla przekształcania wspólnot we współwłasność, zwłaszcza w przypadkach, w których areał gruntów wspólnotowych jest stosunkowo niewielki, a liczba uprawnionych duża. W wyniku takiego przekształcenia wyłącznym właścicielem gruntów stanowiących wcześniej wspólnotę byłaby spółka prawa handlowego, a prawa uprawnionych osób byłyby realizowane w płaszczyźnie korporacyjnej, jako prawa udziałowców. Choć rozwiązanie takie miałoby swoje 
wady (np. koszt utrzymania spółki, konieczność prowadzenia rachunkowości itp.), to z drugiej strony pozwoliłoby uniknąć rozdrabniania własnościowego gruntów, a w konsekwencji ułatwić realizację działań gospodarczych, których przedmiotem mogą być grunty stanowiące dotychczas wspólnoty gruntowe. Rozwiązanie takie ułatwiłoby także realizację zadań z zakresu polityki przestrzennej, w tym przede wszystkim realizację postanowień miejscowych planów zagospodarowania przestrzennego.

Dalsza grupa proponowanych zmian ma przyczynić się do umożliwienia i usprawnienia postępowań zmierzających do uporządkowania i uregulowania stanów prawnych wspólnot gruntowych, przyjmując za podstawowe zasady dotychczas obowiązujące. Proponowany tryb ustalania stanu prawnego wspólnot gruntowych zakłada przeprowadzenie w pierwszej kolejności postępowań zgodnie $\mathrm{z}$ dotychczasowymi przepisami, według stanu na dzień 5 lipca 1963 r. Dotyczyłoby to wskazanych wcześniej około 3500 wspólnot gruntowych, dla których nie wydano decyzji ustalających ich stan prawny. Autorzy założeń do zmian ustawy, słusznie spodziewając się, że w wielu przypadkach ustalenie obecnie stanu prawnego wspólnot gruntowych według stanu obowiązującego w 1963 r. może okazać się niezwykle trudne lub wręcz niemożliwe, proponują, aby w przypadkach, w których zebrany materiał dowodowy nie będzie pozwalał na ustalenie uprawnionych do wspólnoty gruntowej według dotychczasowych zasad, ustalenie stanu prawnego wspólnot gruntowych następowało zgodnie ze stanem faktycznym istniejącym w okresie 5 lat przed dniem wejścia w życie proponowanej ustawy. Z uwagi na fakt, że zdecydowana większość wspólnot gruntowych jest faktycznie użytkowana, przyjęcie proponowanego rozwiązania stwarzałoby możliwość uregulowania większości wspólnot - jeśli nie według stan faktycznego z 1963 r., to według stanu obecnego. Należy się spodziewać, że liczba wspólnot, których stan prawny nie mógłby zostać uregulowany w powyższy sposób, jest rzeczywiście niewielka. W odniesieniu do tego typu wspólnot proponuje się, aby ich własność mogła nabyć gmina, na terenie której nieruchomości wchodzące w skład takiej wspólnoty są położone. Nabycie przez gminę następowałoby na podstawie złożonego przez nią wniosku, a w razie jego niezłożenia, własność takich nieruchomości nabywałby Skarb Państwa. W założeniach Rządu przyjmuje się, że nabycie nieruchomości stanowiących wspólnoty gruntowe następowałoby w drodze decyzji administracyjnej dopiero w przypadku, gdy brak będzie uprawnionych do udziału we wspólnocie gruntowej. Decyzje w tej sprawie wydawałby wojewoda, a organem wyższego stopnia w stosunku do wojewody orzekającego w tych sprawach byłby minister właściwy do spraw rozwoju wsi. Gmina byłaby uprawniona do złożenia wniosku o - jak należy zakładać, nieodpłatne - nabycie nieruchomości w terminie 6 miesięcy od upływu terminu zawitego, jaki przysługiwałby na złożenie takiego wniosku osobom uprawnionym do wspólnoty na podstawie wyżej opisanych przesłanek związanych ze stanem faktycznym ist- 
niejącym w 1963 r. lub w ciągu 5 lat przed wejściem w życie proponowanej regulacji. Gmina mogłaby też złożyć wniosek w terminie 6 miesięcy od daty doręczenia jej decyzji stwierdzającej brak osób uprawnionych do wspólnoty. Nieruchomości nabywane w ten sposób przez gminę miałyby być przeznaczane na cele rozwojowe gminy i zorganizowanej działalności inwestycyjnej, a w szczególności na realizację budownictwa mieszkaniowego oraz związanych z tym budownictwem urządzeń infrastruktury technicznej, a także na realizację innych celów publicznych. Zakładać należy, że nieruchomości takie wchodziłyby do gminnego zasobu nieruchomości i podlegałyby zagospodarowaniu na zasadach określonych przepisach Działu II ustawy o gospodarce nieruchomościami.

W związku z tym, że nabycie nieruchomości stanowiących wspólnoty gruntowe o nieuregulowanym stanie prawnym byłoby prawem, a nie obowiązkiem gminy, w założeniach projektu przyjęto, że w przypadku niezłożenia przez gminę wniosku o nabycie prawa własności opisywanych nieruchomości bądź też w przypadku, gdyby wniosek taki został negatywnie rozpatrzony, ${ }^{24}$ nieruchomości takie stawałyby się z mocy prawa własnością Skarbu Państwa po upływie terminu na złożenie wniosku przez gminę lub z datą, w której decyzja negatywnie rozpatrująca wniosek gminy stawałaby się ostateczna. Decyzję potwierdzającą nabycie nieruchomości przez Skarb Państwa wydawałby wojewoda. Decyzja taka stanowiłaby podstawę do ujawnienia własności Skarbu Państwa w księdze wieczystej oraz w ewidencji gruntów i budynków.

Wydaje się, że przyjęte założenia zmian ustawy w zakresie uporządkowania stanów prawnych wspólnot gruntowych, co do zasady, zmierzają ku przyjęciu trafnych rozwiązań legislacyjnych. Na aprobatę zasługuje zwłaszcza dążenie do ,kaskadowego" uszeregowania kryteriów ustalania osób uprawnionych do wspólnot z jednoczesnym przyznaniem pierwszeństwa kryteriom dotychczasowym, tj. ustalaniu kręgu uprawnionych według stanu faktycznego istniejącego w 1963 r. Dopiero gdy nie uda się ustalić kręgu uprawnionych w ten sposób, pod uwagę brany byłby stan faktyczny istniejący współcześnie. Przejmowanie własności gruntów stanowiących wspólnoty gruntowe przez gminę, a ewentualnie w dalszej kolejności przez Skarb Państwa, wchodziłoby w grę dopiero w sytuacji, w której nie uda się ustalić uprawnionych spośród rolników-właścicieli gospodarstw rolnych. Kwestią, która została jednak całkowicie pominięta w założeniach projektu, jest tryb zgłaszania i uregulowania ewentualnych roszczeń osób trzecich, które mogłyby im przysługiwać w stosunku do nieruchomości przejmowanych przez gminę. Podobnie zresztą potraktowano tę kwestię przy formułowaniu propozycji dotyczącej przekształcenia wspólnot gruntowych we współwłasność. Jak było to wskazywane na wstępie, wniosku gminy. Zakładać należy, że może do tego dojść wyłącznie w przypadku złożenia wadliwego wniosku, który nie zostałby następnie uzupełniony w terminie. 
w skład wspólnot gruntowych wchodzą nie tylko grunty stanowiące, jak to przyjęto określać „szczególny rodzaj współwłasności” osób uprawnionych do wspólnoty, ale także grunty stanowiące cudzą własność, do których uprawnionym do wspólnoty przysługuje jedynie prawo użytkowania. Nie sposób zatem wykluczyć, że „,przekształcenie" wspólnoty we współwłasność może w niektórych przypadkach łączyć się z odjęciem określonych praw majątkowych osobom, którym tego typu prawa w stosunku do nieruchomości dotychczas przysługiwały.

Aby rozwiązać ten problem, można sięgnąć do rozwiązań przyjmowanych w odniesieniu do innych norm o charakterze regulacyjnym. Przykładem może być rozwiązanie przyjęte $\mathrm{w}$ art. 73 ustawy z dnia 13 października $1998 \mathrm{r}$. Przepisy wprowadzające ustawy reformujące administrację publiczną. ${ }^{25}$ Zgodnie $\mathrm{z}$ tym przepisem nieruchomości pozostające w dniu 31 grudnia 1998 r. we władaniu Skarbu Państwa lub jednostek samorządu terytorialnego, nie stanowiące ich własności a zajęte pod drogi publiczne, z dniem 1 stycznia 1999 r. stały się z mocy prawa własnością Skarbu Państwa lub właściwych jednostek samorządu terytorialnego za odszkodowaniem. ${ }^{26}$ Odszkodowania były ustalane i wypłacane według zasad i trybu określonych w przepisach o odszkodowaniach za wywłaszczone nieruchomości, na wniosek właściciela nieruchomości złożony w okresie od dnia 1 stycznia 2001 r. do dnia 31 grudnia 2005 r. Po upływie tego okresu roszczenie wygasało. O rozwiązaniach problemów związanych z regulowaniem stanów prawnych wspólnot gruntowych, m.in. przez wykup obciążeń, wspomina także J. Szachułowicz. ${ }^{27}$

Propozycje sformułowane w omawianych założeniach do projektu ustawy nie ograniczają się jednak wyłącznie do regulowania stanów prawnych wspólnot gruntowych i ich ewentualnego przekształcania we współwłasność. Szereg z proponowanych zmian ma dotyczyć usprawnienia funkcjonowania wspólnot gruntowych. Część propozycji dotyczy ustroju spółek powołanych do sprawowania zarządu nad wspólnotą gruntową przez uzupełnienie art. 17 ustawy określającego treść statutu (w zakresie wskazania przypadków wymagających zwołania zebrania członków spółki oraz warunków zaciągania zobowiązań i udzielania pełnomocnictw do reprezentowania spółki) oraz art. $18 \mathrm{w}$ zakresie formy, w której następuje zatwierdzenie statutu spółki przez wójtów (burmistrzów, prezydentów miast). Proponuje się także wprowadzić przepisy wzmacniające pozycję prawną członków spółki w ten sposób, aby przyznać im prawo zaskarżania uchwał spółek do sądu, jeżeli naruszałyby ich interesy jako członków spółki, w szczególności z powodu niezgodności uchwał z przepisami prawa lub ze statutem, jeżeli naruszałyby zasady właściwego zagospodarowania gruntów wchodzących w skład wspólnoty gruntowej.

Dz.U. Nr 133, poz. 872 z późn. zm.

Podstawę do ustalenia wysokości odszkodowania stanowiła wartość nieruchomości według stanu z dnia wejścia w życie ustawy, przy czym nie uwzględnia się wzrostu wartości nieruchomości spowodowanego trwałymi nakładami poczynionymi po utracie przez osobę uprawnioną prawa do władania gruntem. 
Reasumując powyższe uwagi, należy uznać, że proponowane zmiany unormowań prawnych zmierzają w kierunku rzeczywistego rozwiązania podstawowego zagadnienia związanego z problematyką wspólnot gruntowych, jakim jest ich nieuregulowany stan prawny. Opierają się one na założeniu pozostawienia w dotychczasowym stanie wspólnot aktywnie zarządzanych, o ustalonym statusie prawnym (z możliwością ich przekształcenia we współwłasność) i komunalizacji „gruntów wspólnotowych porzuconych". Rozwiązanie tego problemu przyczyni się niewątpliwie do podniesienia efektywności gospodarczego wykorzystania sporego areału gruntów, jakie w skali kraju stanowią wspólnoty gruntowe. Proponowane umożliwienie przekształcania wspólnot gruntowych we współwłasność, przy założeniu rozwiązania sygnalizowanych wyżej problemów, może także przyczynić się do ułatwienia obrotu tymi nieruchomościami na rynku, co może wywrzeć bardzo korzystny skutek zwłaszcza na obszarach podlegających procesom urbanizacji. ${ }^{28}$ Uregulowanie stanu prawnego wspólnot gruntowych przyczyniłoby się niewątpliwie także do zwiększenia wpływów samorządów gminnych z tytułu podatków, a także ułatwiłoby realizację rozstrzygnięć przyjmowanych w miejscowych planach zagospodarowania przestrzennego. Na aprobatę wreszcie zasługuje przyjęty sposób regulacji utrzymujący jako priorytetowy sposób regulowania stanów prawnych wspólnot według zasad dotychczasowych oraz, co najważniejsze, unikający sugerowanych w niektórych wypowiedziach doktryny rozwiązań zmierzających do „odgórnej” likwidacji wszystkich wspólnot gruntowych jako nieprzystającego do współczesnych uwarunkowań społeczno-gospodarczych reliktu feudalnych stosunków własnościowych. Wynikiem takiego błędnego podejścia byłaby likwidacja nie tylko istniejącej, jak wskazywano powyżej, od ponad 660 lat wspólnoty „Piwniczna-Szyja”, ale także wielu innych wspólnot, które pełnią nie tylko funkcje gospodarcze, ale odgrywają również istotną rolę w budowaniu tożsamości lokalnych społeczności. Na koniec warto jeszcze przywołać przytaczane już w piśmiennictwie informacje, że rozwiązania prawno-organizacyjne zbliżone do polskich wspólnot gruntowych występują także w systemach prawnych innych państw, czego przykładem są brytyjskie commons czy też szwajcarskie Allmende..$^{29}$ Można więc postawić tezę, że polskie wspólnoty gruntowe są w pewnym wymiarze elementem wspólnego dziedzictwa europejskiej tradycji prawnej oraz świadectwem wspólnej historii. Choć wartość inwestycyjna gruntów wchodzących w skład tych wspólnot wielokrotnie przewyższa ich wartość „rolniczą”, to grunty te, wobec ograniczeń wynikających z obecnych uregulowań, pozostają praktycznie niedostępne dla inwestorów, pomimo deklarowanej chęci ich zbycia przez uprawnionych do wspólnoty. 
COMMENTS TO THE DRAFT AMENDMENTS TO THE COMMON LANDS ACT

Key words: Common lands, commons, regulation of property rights, agriculture.

Common lands constitute a carry over from the ownership transformations that occurred in Poland during the 19th century as feudalism drew to an end. Common lands constitute a form of joint ownership enjoyed by the residents of a given village. Typically, a villager's share in the common land is based upon the size of the person's farm. The majority of "Commons" were created during the 19th Century, however, in practice some Commons can be traced back more than 600 years.

Today in Poland more than 5,100 Commons exist, covering an area of approximately 107,000 hectares. Of this number, the legal status of nearly 3,500 Commons is not clear, resulting in most of these properties being off the market.

The management and administration of Commons is regulated by the Common Lands Act ("Act") dating back to 1963. Today the Act is inadequate to properly address the current and future use of the Commons. The current mechanism used to determine a person's right to use a particular common land, as well as his or her share in ownership, is inadequate and inefficient.

In response to the growing difficulties in managing the Commons, the Polish government is currently working to amend the Act. Once enacted, the proposed amendments are intended to implement a new set of rules to determine the legal status of the Commons, as well as to determine legal title to such common lands. Under the proposed amendments, the legal status for each property regarded as common land will be determined on the basis of documentation, and in the event such documentation does not exist, on the basis of the factual state of such land during the previous five year period. Within first 6 months following amendment of the Act, interested parties will be able to submit applications to indicate which properties comprise the Commons, and the share of ownership afforded to specific individuals. If a particular Commons is not claimed by entitled parties, ownership of such property will be awarded to the local municipality or to the State Treasury.

This article examines whether the proposed amendments will in fact resolve current questions and disputes regarding the legal status of Commons. 